\title{
FAKTOR - FAKTOR YANG BERHUBUNGAN DENGAN PEMANFAATAN PUSAT INFORMASI DAN KONSELING REMAJA (PIK-R) PADA REMAJA DI SMA N 1 SANDEN
}

\author{
Vichi fadzilla, Sitti Nur Djannah \\ Fakultas Kesehatan Masyarakat, Universitas Ahmad Dahlan, Yogyakarta, Indonesia \\ *Correspondence: sitti.nurdjannah@ikm.uad.ac.id \\ Dikirim 3 Desember 2018; Diterima 5 Desember 2018; Publikasi Februari 2019
}

\begin{abstract}
Teenagers have a very complex problem along with the transmission period they experienced. In general, adolescents expressed the need for reproductive health services that is equal to $94.55 \%$ of the total respondents. Only a few respondents stated that they had used a youth service center that was 23.42\%. Utilization of Youth Information and Counseling Center is still very low in Indonesia. Strategies to improve the utilization of the Youth Information and Counseling Center are urgently needed. This study was conducted to determine the relationship between knowledge, attitudes and role of peer educators with the utilization of PIK-R in adolescents in SMA N1 Sanden. This research is a quantitative analytical research with cross sectional approach. Sampling using purposive sampling technique and obtained a sample of 75 members of PIK-R in SMA $N 1$ Sanden. Measurement of variables using questionnaires and tested using Chi square test. The results of this study indicate that the role of peer educators has a significant relationship with the utilization of PIK- $R(p=0.008)$, no knowledge relation $(p=0.218)$ and attitudes about reproductive health $(p=0.072)$ with PIK-R utilization. Peer educator role variables have $R P=2.323$ (95\% CI $=1.284-4.202)$ more than the number 1 means peer educator role is really risk factor. Knowledge and attitude variable have RP value $=0.590(95 \% C I=0.278-1.252)$ and $R P=1.798(95 \% C I=1.029$ 3.143). Conclusion: There is a significant relationship between the role of peer educators and the utilization of PIK-R in adolescents in SMA N 1 Sanden.
\end{abstract}

Keywords: PIK-R utilization, knowledge, attitude, role of peer educator

\section{PENDAHULUAN}

Remaja mempunyai permasalahan yang sangat kompleks seiring dengan masa transmisi yang dialaminya. Sikap permisif, eksperimental seksual dan kurangnya informasi yang akurat menimbulkan ancaman kesehatan seksual remaja. Hal ini ditunjukkan dengan masih rendahnya pengetahuan remaja tentang kesehatan reproduksi. 1 Menanggapi permasalahan tersebut pemerintah bekerjasama dengan BKKBN mengembangkan program kelompok umur sebaya dalam hal ini Pusat Informasi dan Konseling Remaja (PIK-R). Tujuan dari PIK-R ini adalah membantu remaja agar memiliki pengetahuan, kesadaran, sikap dan perilaku kehidupan reproduksi yang sehat.

Berdasarkan hasil laporan dari BKKBN, jumlah PIK - R yang telah terbentuk di Indonesia adalah sebanyak 2.773 PIK - R yang didirikan di sekolah - sekolah sebanyak 55\%, di Lembaga Swadaya Masayarakat (LSM) $15 \%$ dan 35\% yang didirikan di Karang Taruna.

Kebutuhan akan informasi dan pelayanan kesehatan reproduksi pada umumnya, remaja menyatakan sangat membutuhkan pelayanan kesehatan reproduksi yaitu sebesar 94,55\% dari jumlah seluruh responden. Hanya sedikit 
responden yang menyatakan pernah menggunakan pusat pelayanan remaja yaitu 23,42\%. Pemanfaatan Pusat Informasi dan Konseling Remaja masih sangat rendah di Indonesia. Hasil penelitian lain di Semarang dikemukakan bahwa faktor - faktor yang berhubungan dengan pemanfaatan PIK - R meliputi pengetahuan mengenai layanan PIK - R, sikap terhadap kesehatan reproduksi, sikap terhadap layanan PIK - $\mathrm{R}$, dukungan pengurus PIK - R, dukungan teman dan kebutuhan terhadap layanan PIK - R.

Penelitian lain di Pati menyebutkan bahwa pengetahuan, sikap, motivasi dan dukugan guru BK merupakan faktor yang berhubungan dengan pemanfaatan PIK R.5 Program PIK-R di DIY pada sekolah umum atau agama sebanyak 57 sekolah. PIK-R terdapat di 25 sekolah di Kabupaten Kulon Progo, 21 sekolah di Kabupaten Bantul, 4 sekolah di Kabupaten Sleman dan 7 sekolah di Kota Yogyakarta. Kabupaten Bantul memiliki PIK-R tahap tegar yaitu PIK-R Sasayota yang dikelola oleh SMA N 1 Sanden.

PIK (Pusat Informasi dan Konseling) Remaja Sasayota merupakan PIK Remaja yang dimiliki oleh SMAN I Sanden dan merupakan salah satu ekstrakulikuler. PIK Remaja Sasayota memiliki 78 anggota, dibentuk pada tanggal 11 Februari 2007 yang dilantik oleh kepala sekolah serta melibatkan PLKB kecamatan, BKKBN, KUA dan Polsek Sanden dan masih aktif sampai saat ini. PIK - R Sasayota merupakan salah satu PIK - R dalam tahap tegar. Tahap tegar merupakan tahapan yang paling tinggi dalam PIK - R. PIK - R tahap tegar ini bertujuan untuk meningkatkan akses dan kualitas pengelolaan dan pelayanan PIK - $\mathrm{R}$ sehingga jumlah dan kepuasan remaja yang mendapatkan informasi dan konseling melalui PIK - R meningkat.

Permasalahan pada remaja sangat komplek, tidak terkecuali remaja di SMA $\mathrm{N} 1$ Sanden. Hampir semua siswa termasuk anggota PIK - R melakukan pacaran yang tidak diimbangi dengan pengetahuan dan sikap yang benar tentang kesehatan reproduksi. Di SMA N 1 Sanden banyak remaja yang belum mengetahui arti reproduksi dan cara menjaganya, konten pornografi yang tersebar seiring dengan perkembangan teknologi informasi dan remaja sering malu mengungkapkan permasalahannya tentang kesehatan reproduksi. Secara geografis letak SMA N 1 Sanden dekat dengan tempat - tempat wisata seperti pantai samas, pantai kuwaru, pantai pandansimo dan pantai baru yang memberi peluang remaja untuk menyimpang karena di tempat - tempat wisata tersebut sering digelar pesta seks dan banyak kamar - kamar penginapan dengan harga yang terjangkau oleh pelajar.

Program kerja PIK-R Sasayota berjalan sejak terbentuk, tetapi pendamping PIK-R mengalami beberapa halangan salah satunya adalah ketidakpedulian siswa terhadap adanya PIK - R di sekolah. Jumlah siswa yang aktif saat ini berjumlah 576 tetapi yang menjadi anggota PIK - R sebanyak 78 siswa (13,54\%). Data yang diperoleh peneliti pada bulan November 2107, kegiatan pada PIK - R Sasayota rata - rata hanya diikuti oleh 27 anggota saja atau sekitar 34,62\% dari total anggota dan sedikit sekali anggota yang melalukan konseling. Oleh sebab itu, perlu dilakukan penelitian mengenai faktor - faktor yang berhubungan dengan pemanfaatan Pusat Informasi dan Konseling Remaja (PIK - R) Sasayota pada remaja di SMA N 1 Sanden.

\section{METODE PENELITIAN}

Penelitian ini merupakan penelitian analitik kuantitatif dengan rancangan penelitian cross sectional. Penelitian ini ditujukan untuk mengetahui faktor - faktor yang berhubungan dengan pemanfaatan Pusat Informasi dan Koseling Remaja (PIK-R) pada remaja di SMA N 1 Sanden. Peneliti menggunakan rancangan cross 
sectional karena outcame dan paparan diukur dalam satu waktu. Penelitian ini dilakukan di SMA N 1 Sanden.

Pengambilan tempat ini didasari oleh karena SMA N 1 Sanden memiliki PIK$\mathrm{R}$ tahap tegar yaitu tahapan PIK - R paling tinggi. Secara geografis SMA N 1 Sanden dekat dengan tempattempat wisata seperti wisata pantai yang dapat memberikan peluang siswa untuk melakukan seks bebas karena ditempat wisata tersebut terdapat praktik prostitusi.

Populasi dalam penelitian ini adalah siswa dan siswi di SMA N 1 Sanden tahun ajaran 2017 - 2018 yang menjadi anggota PIK - R berjumlah 78. Penentuan jumlah sampel penelitian menggunakan teknik pengambilan sampel purposive sampling. Peneliti memilih responden berdasarkan pada pertimbangan subyektif dan praktis, bahwa responden tersebut dapat memberikan informasi yang memadahi untuk menjawab pertanyaan penelitian.

Instrumen yang digunakan pada penelitian yaitu dengan menggunakan kuesioner. Kuesioner pada penelitian ini merupakan modifikasi dari penelitian yang dilakukan oleh Dias tahun 2016 dan dari buku yang ditulis oleh Priyoto tahun 2014. Kuesioner pada penelitian ini berisi tentang pernyataan tentang pengetahuan kesehatan reproduksi, sikap tentang kesehatan reproduksi, peran pendidik sebaya yang berhubungan dengan pemanfaatan PIK - R pada remaja di SMA N 1 Sanden. Validitas kuesioner penelitian ini dilakukan di SMA N 1 Srandakan pada anggota PIK - R karena karakteristik sekolah dan PIK - R di SMA N 1 Srandakan sama dengan di SMA N 1 Sanden. Kuesioner yang akan diberikan dibagi dalam 4 bagian yaitu 24 butir soal merupakan kuesioner pernyataan pengetahuan tentang kesehatan reproduksi, 15 butir soal merupakan kuesioner pernyataan sikap tentang kesehatan reproduksi, 24 butir soal merupakan kuesioner pernyataan peran pendidik sebaya dan 17 butir soal merupakan kuesioner pernyataan pemanfaatan PIK - R.

Kuesioner pengetahuan menggunakan skala Guttman yang pada jawaban pernyataan menggunakan jawaban benar dan salah. Kuesioner sikap tentang kesehatan reproduksi dalam penelitian menggunakan skala Likert yang pada jawaban pernyataan menggunakan jawaban sangat setuju, setuju, tidak setuju, dan sangat tidak setuju. Peran pendidik sebaya dan pemanfaatan PIK - R dalam penelitian menggunakan skala Likert yang pada jawaban pernyataan menggunakan jawaban selalu, sering, kadang - kadang, tidak pernah dengan tujuan untuk dapat mengetahui tingkatan jawaban siswa.

Analisis data menggunakan analisis univariat dan analisis bivariat. Analisis Univariat bertujuan untuk menjelaskan atau mendeskripsikan karakterisktik responden dan setiap variabel penelitian. Analisis bivariat bertujuan untuk menghasilkan hubungan antara beberapa variabel yang bersangkutan.

\section{HASIL DAN PEMBAHASAN}

Distribusi frekuensi karakteristik responden berdasarkan usia, jenis kelamin, kelas dan keterpaparan terhadap informasi kesehatan reproduksi pada anggota PIKR SMA N 1 sanden disajikan Tabel 2. Karakteristik responden terbanyak berusia 16 tahun (45,3\%), berjenis kelamin perempuan (85,3\%) dari kelas IPA yaitu 53 responden (70,7\%). Karakteristik responden berdasarkan keterpaparan terhadap informasi kesehatan reproduksi diketahui bahwa seluruh (100\%) responden yaitu 75 responden pernah mendapatkan informasi tentang kesehatan reproduksi berupa informasi tentang masa pubertas, Infeksi Menular Seksual (IMS), Kehamilan Tidak Diinginkan (KTD) dan aborsi. 
Tabel 2. Distribusi Frekuensi Karakteristik Responden Berdasarkan Usia, Jenis Kelamin, Kelas dan Keterpaparan Terhadap Informasi Kesehatan Reproduksi pada Anggota PIK-R SMA N 1 Sanden

\begin{tabular}{|l|l|l|l|}
\hline No. & Variabel & Jumlah & \multicolumn{1}{|c|}{$\begin{array}{c}\text { Persentase } \\
(\%)\end{array}$} \\
\hline & Usia & 5 & 6,7 \\
\hline & 15 tahun & 34 & 45,3 \\
\hline & 16 tahun & 25 & 33,3 \\
\hline & 17 tahun & 11 & 14,7 \\
\hline & 18 tahun & 11 & 14,7 \\
\hline & Jenis kelamin & 64 & 85,3 \\
\hline & Laki-laki & \multicolumn{2}{|l|}{} \\
\hline & Perempuan & 53 & 70,7 \\
\hline & Kelas & 22 & 29,3 \\
\hline & IPA & 75 & 100 \\
\hline & IPS & 0 & 0 \\
\hline & Informasi Kesehatan reproduksi \\
\hline & Terpapar & \multicolumn{2}{|l}{} \\
\hline & Tidak Terpapar &
\end{tabular}

Hasil distribusi frekuensi pada setiap variabel penelitian. Tingkat pengetahuan responden tentang kesehatan reproduksi sebagian besar baik yaitu 52 responden (69,3\%). Sikap responden tentang kesehatan reproduksi sebagian besar positif yaitu 44 responden (58,7\%). Responden sebagian besar menyatakan pendidik sebaya berperan yaitu 44 responden (58,7\%). Pemanfaatan PIK-R oleh responden sebagian besar tinggi yaitu 46 responden $(61,3 \%)$.

Distribusi frekuensi variabel penelitian yaitu pengetahuan tentang kesehatan reproduksi, sikap tentang kesehatan reproduksi,peran pendidik sebaya dan pemanfaatan PIK-R disajikan pada tabel 3. Analisis bivariat dilakukan dengan menggunakan analisis uji Chi Square untuk mengetahui hubungan antara variabel bebas yaitu pengetahuan tentang kesehatan reproduksi, sikap tentang kesehatan reproduksi dan peran pendidik sebaya dengan variabel terikat yaitu pemanfaatan PIK-R.

Tabel 3. Distribusi Frekuensi Variabel Penelitian yaitu pengetahuan tentang kesehatan reproduksi, sikap tentang kesehatan reproduksi, peran pendidik sebaya dan pemanfaatan PIK-R

\begin{tabular}{|l|l|l|l|}
\hline No. & Variabel Penelitian & Jumlah & Persentase \\
\hline 1. & Pengetahuan KRR & & \\
\hline & Kurang baik & 23 & 30,7 \\
\hline & Baik & 52 & 69,3 \\
\hline 2. & Sikap KRR & & \\
\hline & Negatif & 31 & 41,3 \\
\hline 3. & Positif & 44 & 58,7 \\
\hline & Keran pendidik & & \\
\hline & Kurang berperan & 31 & 41,3 \\
\hline 4. & Pemanfaatan PIK KRR & 44 & 58,7 \\
\hline & Rendah & & \\
\hline & Tinggi & 29 & 38,7 \\
\hline & Total & 46 & 61,3 \\
\hline & & 75 & 100 \\
\hline
\end{tabular}


Secara deskriptif responden dengan pengetahuan tentang kesehatan reproduksi kurang baik sebagian besar memiliki pemanfaatan PIK-R tinggi yaitu 17 responden (73,9 \%) dan sebagian kecil memiliki pemanfaatan PIKR rendah 6 responden (26,1\%). Responden dengan pengetahuan tentang kesehatan reproduksi baik separuh lebih memiliki pemanfaatan PIK-R tinggi yaitu 29 responden (55,8\%) dan sebagian kecil memiliki pemanfaatan PIK-R rendah 23 responden $(44,2 \%)$.

Tabel 4. Hubungan Pengetahuan tentang Kesehatan Reproduksi dengan Pemanfaatan PIK-R pada Remaja di SMA N 1 Sanden

\begin{tabular}{|c|c|c|c|c|c|c|c|c|}
\hline \multirow[t]{3}{*}{ Pengetahuan } & \multicolumn{6}{|c|}{ Pemanfaatan PKI KRR } & \multirow{3}{*}{$\begin{array}{l}\text { RP (CI } \\
95 \%)\end{array}$} & \multirow{3}{*}{$\begin{array}{l}\mathrm{P} \\
\text { Value }\end{array}$} \\
\hline & \multicolumn{2}{|c|}{ Rendah } & \multicolumn{2}{|c|}{ Tinggi } & \multicolumn{2}{|c|}{ Total } & & \\
\hline & $\mathrm{N}$ & $\%$ & $\mathrm{~N}$ & $\%$ & $\mathrm{~N}$ & $\%$ & & \\
\hline Kurang baik & 6 & 26,1 & 17 & 73,9 & 23 & 100 & 0,590 & 0,218 \\
\hline Baik & 23 & 44,2 & 29 & 55,8 & 52 & 100 & $\begin{array}{l}(0,278- \\
1,252)\end{array}$ & \\
\hline
\end{tabular}

Hasil uji statistik menunjukkan nilai p>0,05, sehingga secara kemaknaan statistik dapat disimpulkan bahwa tidak ada hubungan antara pengetahuan tentang reproduksi dengan pemanfaatan PIK-R pada remaja di SMA N 1 Sanden. Nilai RP (Ratio Prevalence) 0,590 yang artinya responden yang dengan pengetahuan tentang kesehatan reproduksi kurang baik beresiko 0,590 kali mempunyai pemanfaatan PIK-R rendah dibandingan dengan responden dengan pengetahuan tinggi tentang kesehatan reproduksi. Nilai lower-upper CI (95\%) sebesar 0,278-1,252. Secara kemaknaan biologi nilai PR tidak bermakna karena rentang CI melewati angka 1 yang artinya tidak ada pengaruh dan variabel pengetahuan tentang kesehatan reproduksi merupakan faktor pelindung.

Hasil uji statistik memberikan kesimpulan bahwa tidak ada hubungan pengetahuan tentang kesehatan reproduksi dengan pemanfaatan PIK-R pada remaja di SMA N 1 Sanden yang ditunjukkan dengan nilai $\mathrm{p}>0,05(0,218>0,05)$. Siswa yang memiliki pengetahuan tentang kesehatan reproduksi kurang baik sebagian besar memiliki perilaku pemanfaatan PIK-R tinggi dan sebagian kecil siswa yang memiliki perilaku pemanfaatan PIK-R yang rendah. PIK-R di SMA N 1 Sanden merupakan kegiatan ekstrakulikuler, sehingga kemungkinan tingginya pemanfaatan PIK-R disebabkan oleh ketakutan siswa akan mendapat nilai jelek pada kegiatan ekstrakulikuler tersebut. Pengetahuan atau kognitif merupakan domain yang sangat penting untuk membentuk tindakan seseorang.

Perilaku akan bertahan lama apabila berdasarkan pengetahuan, tetapi apabila perilaku tidak berdasarkan pengetahuan dan kesadaran, maka tidak akan bertahan lama. 16 Hal tersebut juga dapat disebabkan adanya faktor lain yang memiliki hubungan lebih signifikan dengan pemanfaatan PIK-R. Misalnya pengetahuan mengenai layanan PIK-R pada siswa tersebut tinggi. Jika siswa telah mempunyai informasi tentang layanan PIK-R misalnya tentang lokasi, tujuan dan ruang lingkup PIK-R dimungkinkan siswa tersebut akan tertarik untuk memanfaatkan PIK-R.

Hasil penelitian Rahayu4 di Semarang dikemukakan bahwa faktor faktor yang berhubungan dengan pemanfaatan PIK - R meliputi pengetahuan 
mengenai layanan PIK - R, sikap terhadap kesehatan reproduksi, sikap terhadapa layanan PIK - R, dukungan pengurus PIK - R, dukungan teman dan kebutuhan terhadap layanan PIK $-\mathrm{R}$.

Hubungan sikap tentang kesehatan reproduksi dengan pemanfaatan PIK-R disajikan pada tabel 5 sebagai berikut:

Tabel 5. Hubungan Sikap tentang Kesehatan Reproduksi dengan Pemanfaatan PIKR pada Remaja di SMA N 1 Sanden

\begin{tabular}{|c|c|c|c|c|c|c|c|c|}
\hline \multirow[t]{3}{*}{ Sikap KRR } & \multicolumn{6}{|c|}{ Pemanfaatan PIK KRR } & \multirow{3}{*}{$\begin{array}{l}\text { RP (CI } \\
95 \%)\end{array}$} & \multirow{3}{*}{$\begin{array}{l}\mathrm{P} \\
\text { Value }\end{array}$} \\
\hline & \multicolumn{2}{|c|}{ Rendah } & \multicolumn{2}{|c|}{ Tinggi } & \multicolumn{2}{|c|}{ Total } & & \\
\hline & $\mathrm{N}$ & $\%$ & $\mathrm{~N}$ & $\%$ & $\overline{\mathrm{N}}$ & $\%$ & & \\
\hline Negatif & 14 & 45,2 & 17 & 54,8 & 31 & 100 & 1,325 & 0,466 \\
\hline Positif & 15 & 34,1 & 29 & 65,9 & 44 & 100 & $\begin{array}{l}\left(0,753^{-}\right. \\
2,331)\end{array}$ & \\
\hline
\end{tabular}

Tabel 5 menunjukkan bahwa responden dengan sikap negatif tentang kesehatan reproduksi separuh lebih memiliki pemanfaatan PIK-R tinggi yaitu 17 responden $(54,8 \%)$ dan sebagian kecil responden memiliki pemanfaatan PIK-R rendah yaitu 14 responden (45,2\%) Responden dengan sikap positif tentang kesehatan reproduksi separuh lebih memiliki pemanfaatan PIK-R tinggi yaitu 29 responden $(65,9 \%)$ dan sebagian kecil responden memiliki pemanfaatan PIK-R rendah yaitu 15 responden (34,1\%).

Hasil uji statistik menunjukkan nilai p>0,05, sehingga secara kemaknaan statistik dapat disimpulkan bahwa tidak ada hubungan antara sikap tentang reproduksi dengan pemanfaatan PIK-R pada remaja di SMA N 1 Sanden. Nilai RP (Ratio Prevalence) 1,325 yang artinya responden yang memiliki sikap negatif tentang kesehatan reproduksi beresiko 1,325 kali memiliki pemanfaatan PIK-R rendah dibandingan dengan responden yang memiliki sikap positif tentang kesehatan reproduksi. Nilai lower-upper CI (95\%) sebesar 0,753-2,331, jadi secara kemaknaan biologi nilai PR tidak bermakna karena rentang CI melewati angka 1 yang artinya tidak ada pengaruh.

Hubungan sikap peran pendidik sebaya dengan pemanfaatan PIK-R disajikan pada tabel 6 sebagai berikut:

Tabel 6. Hubungan Peran Pendidik Sebaya dengan Pemanfaatan PIK-R pada

Remaja di SMA N 1 Sanden

\begin{tabular}{|c|c|c|c|c|c|c|c|c|}
\hline \multirow{3}{*}{$\begin{array}{l}\text { Peran } \\
\text { pendidik } \\
\text { sebaya }\end{array}$} & \multicolumn{6}{|c|}{ Pemanfaatan PIK KRR } & \multirow{3}{*}{$\begin{array}{l}\text { RP (CI } \\
95 \%)\end{array}$} & \multirow{3}{*}{$\begin{array}{l}\mathrm{P} \\
\text { Value }\end{array}$} \\
\hline & \multicolumn{2}{|c|}{ Rendah } & \multicolumn{2}{|c|}{ Tinggi } & \multicolumn{2}{|c|}{ Total } & & \\
\hline & $\mathrm{N}$ & $\%$ & $\mathrm{~N}$ & $\%$ & $\mathrm{~N}$ & $\%$ & & \\
\hline $\begin{array}{l}\text { Kurang } \\
\text { berperan }\end{array}$ & 18 & $58, \mathrm{i}$ & 13 & 41,9 & 31 & 100 & $\begin{array}{l}2,323 \\
(1,284-\end{array}$ & 0,008 \\
\hline Berperan & 11 & 25,0 & 33 & 75,0 & 44 & 100 & $4,202)$ & \\
\hline
\end{tabular}

Tabel 6 menunjukkan bahwa responden yang menyatakan pendidik sebaya kurang berperan, separuh lebih memiliki perilaku pemanfaatan PIK-R rendah yaitu 18 responden $(58,1 \%)$ dan sebagian kecil responden memiliki perilaku pemanfaatan PIK-R tinggi yaitu 13 responden (41,9\%). Responden yang menyatakan pendidik sebaya berperan, sebagian besar memiliki perilaku pemanfaatan PIKR tinggi yaitu 
33 responden (75\%) dan sebagian kecil responden memiliki perilaku pemanfaatan PIK-R rendah yaitu 11 responden (25\%). Hasil uji statistik menunjukkan ada hubungan antara peran pendidik sebaya dengan pemanfaatan PIK KRR.

Hasil uji statistik memberikan kesimpulan bahwa tidak ada hubungan sikap tentang kesehatan reproduksi dengan pemanfaatan PIK-R pada remaja di SMA N 1 Sanden yang ditunjukkan dengan nilai $\mathrm{p}>0,05(0,466>0,05)$. Sikap negatif tentang kesehatan reproduksi adalah kecenderungan untuk menjauhi, menghindari, membenci dan tidak menyukai tentang kesehatan reproduksi. Sikap positif tentang kesehatan reproduksi adalah kecenderungan tindakan mendekati, menyenangi dan mengharapkan PIK-R.

Perilaku seseorang atau masyarakat ditentukan oleh pengetahuan,sikap, kepercayaan, tradisi dari orang atau masyarakat yang bersangkutan. Berdasarkan teori determinan perilaku Lawrence Green (1980) sikap tentang kesehatan reproduksi merupakan faktor predisposisi yang berhubungan dengan perilaku pemanfaatan PIK-R. 17 Sikap mempunyai tiga komponen pokok yaitu kepercayaan, kehidupan emosional dan kecenderungan untuk bertindak (tend to behave). 16 Siswa yang memiliki kepercayaan kuat bahwa hasil dari pemanfaatan PIK-R adalah hal yang positif, maka ia akan memiliki sikap positif terhadap pemanfaatan PIK-R. Kecenderungan untuk bertindak (tend to behave) artinya sikap merupakan komponen yang mendahului tindakan atau perilaku pemanfaatan PIK-R oleh siswa.

Sikap positif terhadap kesehatan reproduksi didasarkan pada keyakinan bahwa kesehatan reproduksi sangat penting untuk dipelajari guna kesehatan reproduksi yang lebih baik untuk remaja (100\%). Sebaliknya siswa yang memiliki keyakinan negatif terhadap kesehatan reproduksi maka akan menganggap kesehatan reproduksi itu tabu dan tidak penting untuk dimengerti. Sikap yang positif terhadap kesehatan reproduksi cenderung membuat siswa melakukan pemanfaatan PIK-R dan sikap negatif tentang kesehatan reproduksi cenderung membuat siswa menjauhi PIK-R. Nilai RP (Ratio Prevalence) 1,798 yang artinya responden yang memiliki sikap negatif tentang kesehatan reproduksi beresiko 1,798 kali memiliki pemanfaatan PIK-R rendah dibandingan dengan responden yang memiliki sikap positif tentang kesehatan reproduksi.

\section{KESIMPULAN}

Tingkat pengetahuan tentang kesehatan reproduksi pada remaja di SMA N 1 Sanden lebih banyak berpengetahuan baik sebesar 69,3\%. Sikap tentang kesehatan reproduksi pada remaja di SMA N 1 Sanden lebih banyak bersikap positif tentang kesehatan reproduksi sebesar $62,7 \%$. Peran pendidik sebaya pada remaja di SMA N 1 Sanden lebih banyak yang berperan yaitu sebesar 58,7\%. Tidak ada hubungan pengetahuan tentang kesehatan reproduksi dengan pemanfaatan PIK-R pada remaja di SMA N 1 Sanden. Tidak ada hubungan sikap tentang kesehatan reproduksi dengan pemanfaatan PIK-R pada remaja di SMA N 1 Sanden. Ada hubungan peran pendidik sebaya dengan pemanfaatan PIK-R pada remaja di SMA N 1 Sanden.

\section{REFERENSI :}

1. Willis, S. 2008. Remaja \& Masalahnya: Mengupas Berbagai Bentuk Kenakalan Remaja Seperti Narkoba, Free Sex Dan Pemecahannya. Bandung : Alfabeta 
2. Kusmiran, E. 2011. Kesehatan Reproduksi Remaja Dan Wanita. Jakarta: Salemba

3. PKBI. 2011. Kebutuhan akan Informasi dan Pelayanan Kesehatan Reproduksi Remaja Laporan Need Assesment di Kupang, Palembang, Singkawang, Cirebon dan Tasikmalaya. Jakarta : PKBI, UNFPA \& BKKBN.

4. Rahayu, Y. S. 2014. "Faktor - Faktor yang Berhubungan dengan Pemanfaatan Layanan Pusat Informasi dan Konseling Kesehatan Reproduksi Remaja (PIK KRR) Kelurahan Jatingaleh Kecamatan Candisari Kota Semarang”. Skripsi, Universitas Diponegoro, Semarang, Tidak diterbitkan

5. Satiti, O. P. 2017. "Faktor - Faktor yang Berhubungan dengan Pemanfaatan PIK - KRR Studi pada SMA, SMK, MA SeKabupaten Pati”. Tesis, Universitas Muhammadiyah Semarang, Semarang, Tidak diterbitkan

6. BKKBN. 2014. Data PIK - R/M, Pendidik Sebaya (PS) dan Konselor Sebaya (KS) Daerah Istimewa Yogyakarta : yogya.bkkbn.go.id diambil pada tanggal 13 Oktober 2017. Yogyakarta

7. Profil sekolah

8. Sulistyaningsih. 2011. Metodologi Penelitian Kebidanan. Yogyakarta : Graha Ilmu

9. Budiman \& Riyanto, A. 2013. Kapita selekta kuesioner pengetahuan dan sikap dalam penelitian kesehatan. Jakarta: Salemba Medika

10. Kusumastuti, D. P. 2016. "Hubungan Pengetahuan dan Sikap Tentang Kesehatan Reproduksi dengan Pemanfaatan Pusat Informasi Dan Konseling Kesehatan Reproduksi Remaja (PIK-KRR) di SMA Negeri 1 Srandakan”. Skripsi, Universitas Gadjah Mada, Yogyakarta, Tidak diterbitkan

11. Rustika, D. R. 2014. "Faktor - Faktor yang Mempengaruhi Pemanfaatan Pusat Informasi dan Konseling Kesehatan Reproduksi Remaja (PIK-KRR) pada Remaja SMA Negeri 5 Yogyakarta Tahun Ajaran 2014”. Skripsi, Universitas Aisyiyah, Yogyakarta, Tidak diterbitkan

12. Yansah, F. 2011. Peran Peer Educator Remaja Dalam Pemberian Informasi Kesehatan Reproduksi Remaja. Bandung : Alfabeta

13. Saito, K. 2009. Performance of Peer Educators on HIV/AIDS Prevention Among High School Students in Bangkok Metropolitan Thailand. Jurnal Maternitas dan Neonatal. Vol. 1, No. 58, Hal. 1-12

14. Kurniawati, H. F. Shaluhiyah, Zahroh. 2014. Pengetahuan Pendidik Sebaya Mempengaruhi Pemberian Informasi KRR di Kabupaten Kulon Progo. Jurnal Promosi Kesehatan Indonesia. Vol. 9, No. 2, Hal. 162-172

15. Afrima, A. 2011. Akseptabilitas dan Pemanfaatan Pusat Informasi dan Konsultasi Kesehatan Reproduksi Remaja (PIK-KRR) pada siswa SMU Di Kota Bima NTB. Universitas Gadjah Mada,Yogyakarta.

16. Notoatmodjo, S. 2011. Kesehatan Masyarakat. Jakarta: Rineka Cipta

17. Notoatmodjo, S. 2014. Ilmu Perilaku Kesehatan. Jakarta: Rineka Cipta

18. Priyoto. 2014. Teori Sikap dan Perilaku dalam Kesehatan. Yogyakarta: Nuha Medika 19. Marmi. 2014. Kesehatan Reproduksi. Yogyakarta : Pustaka Pelajar. 